\title{
(息)
}

Citation:

Bradley, Q (2015) Book Review - When Tenants Claimed the City: The Struggle for Citizenship in New York City Housing. Housing Studies, 30 (7). 1182 - 1183. ISSN 0267-3037 DOI: https://doi.org/10.1080/02673037.2015.1082274

Link to Leeds Beckett Repository record:

https://eprints.leedsbeckett.ac.uk/id/eprint/2168/

Document Version:

Article (Accepted Version)

The aim of the Leeds Beckett Repository is to provide open access to our research, as required by funder policies and permitted by publishers and copyright law.

The Leeds Beckett repository holds a wide range of publications, each of which has been checked for copyright and the relevant embargo period has been applied by the Research Services team.

We operate on a standard take-down policy. If you are the author or publisher of an output and you would like it removed from the repository, please contact us and we will investigate on a case-by-case basis.

Each thesis in the repository has been cleared where necessary by the author for third party copyright. If you would like a thesis to be removed from the repository or believe there is an issue with copyright, please contact us on openaccess@leedsbeckett.ac.uk and we will investigate on a case-by-case basis. 
Book review for Housing Studies

\section{When Tenants Claimed the City: the struggle for citizenship in New York City housing}

By Roberta Gold.

Chicago. University of Illinois Press. 2014. 328pp. Price: $£ 37$ (hdbk)

ISBN: 978-0-252-038818-1

The private rented housing sector is mushrooming in most parts of the world with all its associated problems of insecurity, poor conditions and high rents. Against this background, it is timely to be reminded of what can be achieved by the collective organisation of private tenants and to look to one of the beacons of tenant activism, New York City, for such inspiration. Roberta Gold's study of the New York tenants' movement breaks new ground. Her account of tenants' collective action is situated against the post-war growth of suburban America and in the context of increasing racial and gender segregation. This timeline allows her to present the New York tenants' movement as the expression of an alternative vision of residence and citizenship; one that has strong contemporary resonance:

"They insisted that renters as well as owners had rights to a stable home. They proposed that racially diverse urban communities had a right to remain in place...And they showed that women could participate fully in the political arenas where these issues were fought out. In all these ways New York tenants laid claim to what Marxists have called 'the right to the city', a kind of democratic say over the use of capital to shape the urban environment and the lives of its inhabitants."

The New York tenants' organisations inherited their tradition of radicalism from the communist and anarchist politics of eastern European immigrants who forged a dynamic urban movement in the housing struggles of the late nineteenth and early twentieth century. In situating her analysis of the movement in the post-war years, Gold advances an innovative line of enquiry to shine a light on the missing years of 
American radical politics in the gap between McCarthyism and the birth of the Civil Rights movement. Through her study of tenant activism she is able to shape a narrative of abeyance and social movement continuity where tenant organisations acted as the incubators of the revolutionary spirit of the 1960s and, particularly, of the renaissance of the women's movement. A line of protest is traced through rent strikes and ghetto rebellions, connecting a tradition of community action and neighbouring from resistance to McCarthyite repression to the more spectacular and revolutionary actions of the Black Panthers, the Young Lords and the Weather Underground. Gold provides a scintillating picture of the domestic roots of social movement insurgency, situating women as the instigators and intergenerational bearers of a no-nonsense approach to direct action, inspiring a resurgent spirit of community leadership that has left a rich legacy of legal rights and protections for tenants still thriving despite the impact of property booms and the incursions of affluent incomers. The tenants' movement regenerated the inner city and breathed new life into the political left.

Tenant history is palpable in the political culture of community and housing rights that makes New York distinct and supports the survival of its large public housing stock. Gold's account of the lasting achievements of New York tenants is highly topical not only in its implications for a more socially just private rented sector, but in what it says about the losses and gains of homeownership as the dominant model of citizenship. The notion of neighbourhood diversity that motivates so much of contemporary housing and planning policy was forged by a movement that celebrated the inner city at a time when everyone else was flocking to the supposed ideal life in the suburbs. Tenant activism posited a model of residential citizenship that was successful in championing the rights of renters to community life and in originating a captivating image of urban neighbourliness that was distinctive in its multi-racial appeal and in its resistance to the forces of property speculation. This claim to community was rooted in feminist thought and shaped by anti-racist struggle, and Gold's analysis situates the diverse urban neighbourhood so beloved of urban designers and politicians as the outcome of tenant collective action. She recovers a radical history of neighbourhood self-management and community control that provides a critical reflection on the discourses of localism in planning and urban regeneration, and illuminates the conflicts of present day gentrification. 
In situating the movement within its political traditions and connections, Gold reminds us that affordable and secure housing is the basis of just social policy and its denial is a recipe for unending conflict and discord. Segregation on income, class and ethnicity is tolerated, and actually celebrated, once again in urban policy. The displacement of urban populations through gentrification is positively encouraged as a strategy of regeneration. Rationalities of government give unfettered rein to the uneven development of market forces and the provision of public and affordable housing is almost everywhere reduced and denigrated. While the achievements of the New York tenants' movement represent a rare exemption from this trend, they also show that campaigns for housing justice can survive political repression and ideological downturns; that they continue generation after generation, and will emerge again, perhaps more vividly and effectively. Gold's account shows that the struggle for decent housing is integral to our understandings of citizenship and community; and it is a struggle that will not go away.

Dr. Quintin Bradley

Senior Lecturer in Housing \& Planning

Leeds Beckett University 